\title{
The relationship of five personality factors with the feeling of happiness among students
}

\author{
Mohamad Khaledian ${ }^{1, *}$, Zahra Ahmadimehr ${ }^{2}$, Elham Naseri ${ }^{3}$, \\ Fakhralsadat Khosravani ${ }^{4}$, Mojgan Shoshtsri ${ }^{5}$ \\ ${ }^{1}$ Faculty of Psychology, Ghorveh Branch, Islamic Azad University, Ghorveh, Iran \\ ${ }^{2}$ Masters Student in General Psychology of Science and Research Isfahan Branch, \\ Islamic Azad University, Isfahan, Iran \\ ${ }^{3}$ Faculty of Psychology, Payame Noor University, PO BOX 19395-3697, Tehran, Iran \\ ${ }^{4} \mathrm{M} . \mathrm{A}$ in General Psychology Khorasegan Branch Islamic Azad University, \\ Khorasegan (Isfahan), Iran \\ ${ }^{5}$ Student PhD of Psychology and Education of Children with Special Needs of Isfahan, \\ Payame Noor University, PO BOX 19395-3697, Tehran, Iran \\ *E-mail address: Mohamad_khaledian22@yahoo.com
}

\begin{abstract}
The aim of the present research was to investigate the relationship between the five personality factors among the feeling of happiness among students. The present research statistics included all the B.A. students of Payame Noor of Bijar in the year 2012-2013. The sample size of 100 students (boys and girls) was selected using the simple random sampling method. To collect data, 60 item Neo Five Factor Personality Test questionnaire and the 29 item Oxford Happiness questionnaire were used. In order to analyze the data, the Pearson correlation coefficient was also used. The findings indicated that there is a significant and positive relationship between happiness and extraversion, openness, agreeableness and conscientiousness while there is a negative and significant relationship between happiness and neuroticism.
\end{abstract}

Keywords: Happiness; Personality; NEO Personality Test

\section{INTRODUCTION}

Familiarity with cases like ordinary patterns of individual response helps predict his behavior quality in a new and particular situation. These responses usually originate from people's personality characteristics. Each constant personality characteristics limits the personal approach to stress generating situations, for his special thinking and behavior styles allow for definite and limited responses. Hence, people's personality characteristics could engender personal differences in the field of health. Happiness is one of the mental health standards of people. Happiness derives from a coordinated action of all the emotions of a totally integrated and coordinated personality in which main feelings strengthen each other in a series of actions, all directed at one or more goals that are almost, unified and coordinated (Marshal Reeve, 2006). In the positive psychology, instead of placing an emphasis on identifying and 
studying mental shortcomings and behavioral defects and treating them, there is an emphasis on recognizing and promoting positive features and weakness points of man.

Thus, happiness is one of positive aspects of psychology, originating from the man's judgment as with regards to the way life is spent. This judgment has an internal quality and is affected by positive emotions (Myers and Diener, 1995). Happiness is based on personal attitudes and intuitions, implying a pleasing and favorable quality that originates from positive emotions and being satisfied with life (Hills and Argyle, 2001). Kettel regards personality as allowing the prediction of what a person does at a particular situation (Schults and Schults 2006, trans. Seid Mohamadi, 2009). McCrae and Costa have identified the five personality factors as:

1. Neuroticism $(\mathrm{N})$

2. Extraversion $(\mathrm{E})$

3. Openness $(\mathrm{O})$

4. Agreebleness (A)

5. Conscientiousness $(\mathrm{C})$

These factors were confirmed through a variety of assessment techniques including self evaluative questionnaires, objective tests and the reports by the observers (McCrae and Costa,1997). McCrae and Costa have pointed out that the five main factors and their attributes are indicative of a shared human personality structure (McCrae and Costa, 1997). Today most researchers believe the five personality factors model as a multi level framework could increase our knowledge about personality and health (Pour Esmaeeli et al, 2011). In addition to being unique, personality is affected by the society, culture and race (Yong, 1969).

The McCrae and Costa's framework was used for investigating personality characteristics. In this framework the five personality characteristics titled as extraversion, openness to new experiences, agreeableness and conscientiousness and neuroticism have been identified. Neuroticism refers to lack of security, emotional instability and immaturity. Extraversion is defined by socialization, self motivation and being adventurous. Openness is related to mental capacity, imagination and diversity. Agreeableness is related to candor, courtesy, humility and kindness. Conscientiousness refers to such characteristics as responsibility, the ability to trust and being organized (Hazrati, et al, 20011).

The research findings by Haghighi et al (2007), with the subject of the relationship between the five personality factors and the feeling of happiness among the B.A. students of the Shahid Chasmran University indicated that there is a significant correlation between these five factors and the feeling of happiness. In this research the relationship of the five personality factors and the feeling of happiness among students in the year 2012-2013 was investigated and recommendations based on the findings of the research are going to be presented to parents, students, academic personnel so as to make them be aware of the relationship between the five factors and the feeling of happiness.

Thus, based on these recommendations they will be able to intelligently and orderly create a situation so that students and the people of the society are guided to a healthier and more successful life and the situation is prepared for nurturing abilities and raising more efficient human force and creating a better future. 


\section{METHODOLOGY}

In this research the relationship between the five factors of personality and the feeling of happiness among students based on the Argyle and Lu questionnaire and the Neo five factor questionnaires is investigated. The present research statistics included all the B.A. students of Payame Noor of Bijar in the year 2012-2013. The sample size of 100 students (boys and girls) was selected using the simple random sampling method.

\section{1. Oxford happiness questionnaire}

This tool was designed by Argyle and Lu IN 1989. This questionnaire has 29 four choice articles whose choices are ranked from 0 to 3 respectively and the total score of the 29 articles, forms the total score of the scale. The total score of the subject fluctuates from 0 to 87 . In their research, Ali Pour and Nour Bala (2002) showed that all the 29 articles of the test had high correlation with the total score and the Cronbach's alpha of 0/93 and the reliability of the making of the test split half was reported as 0/92.

In this research the Cronbach's alpha for the questionnaire was 0/926.

\section{2. NEO five factor questionnaire (NEO-FFI)}

This questionnaire has 60 items that evaluates the five dimensions of the normal personality. These five dimensions are extraversion, openness, agreeableness and conscientiousness and neuroticism. Each dimension has 12 items. The subject is required to identify his own agreement and disagreement on the five degree Likert scale with regards to an understanding of himself. ( $1=$ totally disagree and $5=$ totally agree). Higher scores show more neuroticism, extraversion, experience, agreeableness and conscientiousness. McCrae and Costa(1987) applied the NEO-PI-R scale simultaneously so as to investigate the validity of the NEO-FFI and the validity coefficients of $0 / 75,0 / 80,0 / 74,0 / 71$ and $0 / 77$ were reported for the factors of neuroticism, extraversion, experience, agreeableness and conscientiousness. Attari et al (2006), reported the reliability of this test, using the retest method on 64 people for a two week interval for the factors of N, E, O, A, and C respectively. Various researches have used the Cronbach's alpha for showing the internal parallelism. Nilforooshan et al, (2002), reported cronbach's alpha coefficients of $0 / 76,0 / 63,0 / 31,0 / 48$ and $0 / 81$ for these factors respectively.

\section{FINDINGS}

Table 1. The descriptive indices of personality characteristics and happiness of students.

\begin{tabular}{|c|c|c|}
\hline Variables & Mean & Standard deviation \\
\hline Neuroticism & $21 / 49$ & $5 / 88$ \\
\hline Extraversion & $28 / 35$ & $6 / 50$ \\
\hline Openness & $28 / 25$ & $4 / 10$ \\
\hline Agreeableness & $33 / 27$ & $5 / 41$ \\
\hline Conscientiousness & $34 / 59$ & $6 / 68$ \\
\hline Feeling of happiness & $41 / 18$ & $11 / 05$ \\
\hline
\end{tabular}

$\mathrm{N}=100$ 
Table 2. The correlation of personality characteristics with the feeling of happiness.

\begin{tabular}{|c|c|c|c|c|c|}
\hline \multirow{2}{*}{$\begin{array}{c}\text { Criterion } \\
\text { variable }\end{array}$} & \multirow{2}{*}{ Prediction variable } & $\begin{array}{l}\text { Statistical } \\
\text { indices }\end{array}$ & \multirow{2}{*}{$\begin{array}{c}\text { Correlation } \\
\text { coefficient (r) }\end{array}$} & \multirow{2}{*}{$\begin{array}{l}\text { Sig. level } \\
\text { (p) }\end{array}$} & \multirow{2}{*}{$\begin{array}{l}\text { Number of } \\
\text { sample (n) }\end{array}$} \\
\hline & & Group & & & \\
\hline \multirow{15}{*}{$\begin{array}{l}\text { Feeling of } \\
\text { happiness }\end{array}$} & \multirow{3}{*}{ Neuroticism } & $\begin{array}{l}\text { All the } \\
\text { students }\end{array}$ & $-0 / 52$ & $0 / 0001$ & 100 \\
\hline & & $\begin{array}{c}\text { Girl } \\
\text { students }\end{array}$ & $-0 / 55$ & $0 / 0001$ & 50 \\
\hline & & $\begin{array}{c}\text { Boy } \\
\text { students }\end{array}$ & $-0 / 40$ & $0 / 0001$ & 50 \\
\hline & \multirow{3}{*}{ Extraversion } & $\begin{array}{l}\text { All the } \\
\text { students }\end{array}$ & $0 / 55$ & $0 / 0001$ & 100 \\
\hline & & $\begin{array}{c}\text { Girl } \\
\text { students }\end{array}$ & $0 / 49$ & $0 / 0001$ & 50 \\
\hline & & $\begin{array}{c}\text { Boy } \\
\text { students }\end{array}$ & $0 / 61$ & $0 / 0001$ & 50 \\
\hline & \multirow{3}{*}{ Openness } & $\begin{array}{l}\text { All the } \\
\text { students }\end{array}$ & $0 / 48$ & $0 / 0001$ & 100 \\
\hline & & $\begin{array}{c}\text { Girl } \\
\text { students }\end{array}$ & $0 / 41$ & $0 / 0001$ & 50 \\
\hline & & $\begin{array}{c}\text { Boy } \\
\text { students }\end{array}$ & $0 / 55$ & $0 / 0004$ & 50 \\
\hline & \multirow{3}{*}{ Agreeableness } & $\begin{array}{l}\text { All the } \\
\text { students }\end{array}$ & $0 / 48$ & $0 / 0001$ & 100 \\
\hline & & $\begin{array}{c}\text { Girl } \\
\text { students }\end{array}$ & $0 / 45$ & $0 / 0001$ & 50 \\
\hline & & $\begin{array}{c}\text { Boy } \\
\text { students }\end{array}$ & $0 / 50$ & $0 / 0001$ & 50 \\
\hline & \multirow{3}{*}{ Conscientiousness } & $\begin{array}{l}\text { All the } \\
\text { students }\end{array}$ & $0 / 43$ & $0 / 0001$ & 100 \\
\hline & & $\begin{array}{c}\text { Girl } \\
\text { students }\end{array}$ & $0 / 42$ & $0 / 0001$ & 50 \\
\hline & & $\begin{array}{c}\text { Boy } \\
\text { students }\end{array}$ & $0 / 43$ & $0 / 0001$ & 50 \\
\hline
\end{tabular}




\section{DISCUSSION AND CONCLUSION}

The aim of the present research is to investigate the r4elationship of the five personality factors and the feeling of happiness that based on the findings of the present research, it can be concluded that there is a negative correlation between the neuroticism and happiness and a positive correlation between happiness and other personality characteristics that are in line with the findings of the research by Haghighi et al (2007). In explaining these findings, it can be said that happiness is equivalent to rehabilitation mnd the mental well fare. All attempt to feel comfort and refrain from suffering.

Therefore, the feeling of happiness contrasts with neuroticism and the existence of one of them means the lack of the other. Also the results of the research indicate that there is a positive correlation between extroversion and the feeling of happiness. Usually extroversion has a close link with movement and communication and hence, this will lead to acceptance, group and addressees orientation. Extroversion has a close relation with positive emotions and having skill in generating cheerful situations. In explaining the positive correlation between agreeableness and the feeling of happiness, it can be said that, sine agreeable people are able to adapt to different situations feel more happy and cheerful.

Of the delimitations of the research are the lack of access to the students intelligent level and their exact cultural and economic status and their effects on the personality characteristics as well as the feeling of happiness and lack of awareness of their benefiting from an appropriate education and also lack of access to the emotional problems of the students. It is recommended that given the fact that in different cultures happiness is understood differently and there are different concepts of happiness and most of the definitions are taken from the western origins, qualitative researches are performed on different concepts of happiness in the country. It is also recommended that researchers follow this important topic at other universities.

\section{References}

[1] Ali Pour A., Noor Bala A. (2002). An introductory investigation of the reliability and validity of the Oxford happiness questionnaire among students in Tehran. Andishe and Raftar journal.

[2] Argyl M., Lu L. (1989). The happiness of extraverts. Personality and individual Differences, 11, 1011-1017.

[3] Attari F., Amanolahifard A., Mehrabizadeh M. (2006). The relationship between personality characteristics and interpersonal factors - the state Department of Family and marital satisfaction in Ahwaz. Journal of Educational Science and Psychology, 3(1), 81-108.

[4] Costa Jr. P. T., McCrae R. R. (1992). Revised NEO Personality Inventory (NEO-PI-R) and NEO Five-factor Inventory (NEO-FFI): Professional manual. Odessa: Psychological Assessment Resources INC

[5] Haghighi J., Khosh Konesh A., Shekarshkan H., Shahanri M., Nisi A. (2007). The relationship of the personality five factors with the feeling of happiness in students undergraduate at the University of Shahid Chamran. Psychology journal of the University of Shahid Chamran, 13(3), 163-188. 
[6] Hazrati A., Tayrani A., Yazdan Panah M. A. (2011). The role of personality characteristics in predicting educational motivation of students. Moaser psychology periodical, 5, 280-282.

[7] Hills P., Argyle M. (2001). Happiness, Introversion-extraversion and happy introverts. Personality and individual Differences, 30, 595- 608.

[8] Ung C. G. (1969). The structure and dynamcs of the psyche (2nd ed.). Princeton, NJ: Princeton University Press.

[9] Marshalreeve J. (2006). Motivation and emotion. (trans. Yahya Seid Mohamadi). Tehran: Nashr publication.

[10] McCrae R. R., Costa P. T. Jr. (1987). Validation of the five-factor Model of personality across instrument and observers. Journal of Personality and Social Psychology, 52, 81-90.

[11] McCrae R. R., Costa P. T. Jr. (1997). Personality trait structure as a human universal. American Psychologist, 52, 509-516.

[12] Myers D. G., Diener E. (1995). Who is happy? Psychological Sciences, 6, 10-19.

[13] Nilforooshan P., Ahmadi S. A., Fatehi zade, M., Abedi, M. R., Ghasemi V. (2012). The relationship of attachment styles dimensions with the personality five factors from a couple and individual perspective. Journal of Family Research, 6(22), 252-272.

[14] Pour Esmaeeli A., Berahmand O., Andalib M., Salehi M., Khosroyan B. (2011). Personality five factors and forgiveness among students. Moaser psychology periodical, 5, 190-192.

[15] Schults D., Schults S. A. (2006). Personality theories. (trans. Yahya Seid Mohamadi). Tehran: Virayesh publication. 